\title{
Structures and Properties of Zirconia-Supported Ruthenium Oxide Catalysts for the Selective Oxidation of Methanol to Methyl Formate
}

\author{
Weizhen Li, ${ }^{\dagger}$ Haichao Liu, ${ }^{*}, \dagger$ and Enrique Iglesia ${ }^{*}$ \\ Beijing National Laboratory for Molecular Sciences, State Key Laboratory for Structural Chemistry of Stable \\ and Unstable Species, College of Chemistry and Molecular Engineering, Green Chemistry Center, Peking \\ University, Beijing 100871, China, and Department of Chemical Engineering, University of California at \\ Berkeley, Berkeley, California 94720
}

Received: July 30, 2006; In Final Form: September 15, 2006

\begin{abstract}
The effects of $\mathrm{RuO}_{x}$ structure on the selective oxidation of methanol to methyl formate (MF) at low temperatures were examined on $\mathrm{ZrO}_{2}$-supported $\mathrm{RuO}_{x}$ catalysts with a range of $\mathrm{Ru}$ surface densities $\left(0.2-3.8 \mathrm{Ru} / \mathrm{nm}^{2}\right)$. Their structure was characterized using complementary methods (X-ray diffraction, Raman and X-ray photoelectron spectra, and reduction dynamics). The structure and reactivity of $\mathrm{RuO}_{x}$ species change markedly with $\mathrm{Ru}$ surface density. $\mathrm{RuO}_{x}$ existed preferentially as $\mathrm{RuO}_{4}{ }^{2-}$ species below $0.4 \mathrm{Ru} / \mathrm{nm}^{2}$, probably as isolated $\mathrm{Zr}\left(\mathrm{RuO}_{4}\right)_{2}$ interacting with $\mathrm{ZrO}_{2}$ surfaces. At higher surface densities, highly dispersed $\mathrm{RuO}_{2}$ domains coexisted with $\mathrm{RuO}_{4}{ }^{2-}$ and ultimately formed small clusters and became the prevalent form of $\mathrm{RuO}_{x}$ above $1.9 \mathrm{Ru} / \mathrm{nm}^{2}$. $\mathrm{CH}_{3} \mathrm{OH}$ oxidation rates per $\mathrm{Ru}$ atom and per exposed $\mathrm{Ru}$ atom (turnover rates) decreased with increasing $\mathrm{Ru}$ surface density. This behavior reflects a decrease in intrinsic reactivity as $\mathrm{RuO}_{x}$ evolved from $\mathrm{RuO}_{4}{ }^{2-}$ to $\mathrm{RuO}_{2}$, a conclusion confirmed by transient anaerobic reactions of $\mathrm{CH}_{3} \mathrm{OH}$ and by an excellent correlation between reaction rates and the number of $\mathrm{RuO}_{4}{ }^{2-}$ species in $\mathrm{RuO}_{x} / \mathrm{ZrO}_{2}$ catalysts. The high intrinsic reactivity of $\mathrm{RuO}_{4}{ }^{2-}$ structures reflects their higher reducibility, which favors the reduction process required for the kinetically relevant $\mathrm{C}-\mathrm{H}$ bond activation step in redox cycles using lattice oxygen atoms involved in $\mathrm{CH}_{3^{-}}$ $\mathrm{OH}$ oxidation catalysis. These more reactive $\mathrm{RuO}_{4}{ }^{2-}$ species and the more exposed $\mathrm{ZrO}_{2}$ surfaces on samples with low Ru surface density led to high MF selectivities (e.g. $\sim 96 \%$ at $0.2 \mathrm{Ru} / \mathrm{nm}^{2}$ ). These findings provide guidance for the design of more effective catalysts for the oxidation of alkanes, alkenes, and alcohols by the synthesis of denser $\mathrm{Zr}\left(\mathrm{RuO}_{4}\right)_{2}$ monolayers on $\mathrm{ZrO}_{2}$ and other high surface area supports.
\end{abstract}

\section{Introduction}

Methyl formate $\left(\mathrm{HCOOCH}_{3} ; \mathrm{MF}\right)$ is an important chemical precursor to other chemicals, such as carboxylic acids, esters, and formamides, ${ }^{1-4}$ and in the synthesis of ethylene glycol. MF synthesis currently involves the carbonylation of methanol with $\mathrm{CO}$ using strong liquid bases such as sodium methoxide or nonoxidative dehydrogenation of methanol on CuO-based catalysts. $^{2-5}$ These processes involve waste byproducts, energy inefficiencies, or thermodynamic constraints. Oxidation processes are catalyzed by dispersed $\mathrm{VO}_{x}$ and $\mathrm{MoO}_{x}$ domains ${ }^{4-7}$ with favorable thermodynamics and modest MF selectivities, but improvements in reaction rates and selectivities are required for industrial practice.

The oxidation of methanol to $\mathrm{MF}$ on $\mathrm{VO}_{x}$ and $\mathrm{MoO}_{x}$ catalysts involves rate-determining $\mathrm{C}-\mathrm{H}$ bond activation steps to form $\mathrm{HCHO}$ and their subsequent reactions with intermediates derived from $\mathrm{CH}_{3} \mathrm{OH}$ or $\mathrm{HCHO},{ }^{1,8,9}$ which also form $\mathrm{CO}_{x}\left(\mathrm{CO}+\mathrm{CO}_{2}\right)$ at the conditions required for $\mathrm{HCHO}$ formation. $\mathrm{RuO}_{x}$ domains dispersed on $\mathrm{ZrO}_{2}, \mathrm{TiO}_{2}, \mathrm{SnO}_{2}, \mathrm{Al}_{2} \mathrm{O}_{3}$, or $\mathrm{SiO}_{2}$ catalyze $\mathrm{CH}_{3-}$ $\mathrm{OH}$ oxidation to $\mathrm{HCHO}$ at unprecedented low temperatures (330-400 K). HCHO then converts to dimethoxymethane (DMM) or MF via methoxymethanol or hemiacetal intermediates (Scheme 1). ${ }^{10}$ Supports influence secondary reactions of

* Author to whom correspondence should be addressed (e-mail hcliu@pku.edu.cn; telephone/fax 86-10-6275-4031).

$\dagger$ Peking University.

$\doteqdot$ University of California at Berkeley.
SCHEME 1: Primary and Secondary $\mathrm{CH}_{3} \mathrm{OH}$ Reaction Pathways on Supported $\mathrm{RuO}_{x}$ Catalysts

$\mathrm{CH}_{3} \mathrm{OH}$

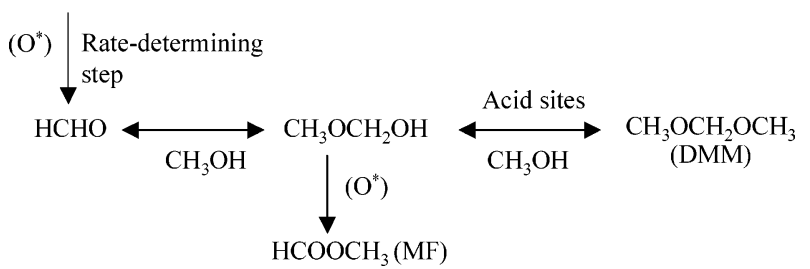

$\mathrm{HCHO}$ and other intermediates and also the redox properties of $\mathrm{RuO}_{x}$ domains. $\mathrm{ZrO}_{2}$ supports led to the highest $\mathrm{MF}$ rates and yields, but also to the highest selectivity to undesired $\mathrm{CO}_{2} \cdot{ }^{10}$

The specific control of structure and atomic connectivity in dispersed oxides remains a critical challenge in the improvement of catalytic performance. ${ }^{11-17}$ Here, we probe the relationship between the structure of $\mathrm{RuO}_{x}$ domains supported on $\mathrm{ZrO}_{2}$ and their redox and catalytic properties during the oxidation of methanol to MF, with the aim to design more effective catalysts for $\mathrm{MF}$ synthesis. The structure of $\mathrm{RuO}_{x}$ domains with a range of Ru surface densities $\left(\sim 0.2-4 \mathrm{Ru} / \mathrm{nm}^{2}\right)$ was characterized by X-ray diffraction (XRD) and X-ray photoelectron (XPS) and Raman spectroscopies. The reducibility of $\mathrm{RuO}_{x}$ species was probed by temperature-programmed reduction (TPR) in $\mathrm{H}_{2}$. $\mathrm{RuO}_{4}{ }^{2-}$ structures, containing $\mathrm{Ru}^{6+}$ and likely present as $\mathrm{Zr}$ $\left(\mathrm{RuO}_{4}\right)_{2}$, were detected and found to be active and selective for MF synthesis. 


\section{Experimental Methods}

Synthesis and Characterization of Catalysts. $\mathrm{ZrO}_{2}$-supported $\mathrm{RuO}_{x}$ catalysts (denoted $\mathrm{RuO}_{x} / \mathrm{ZrO}_{2}$ ) were prepared by incipient wetness impregnation of $\mathrm{ZrO}_{2}$ with an aqueous solution of $\mathrm{Ru}(\mathrm{NO})\left(\mathrm{NO}_{3}\right)_{3}$ (Alfa Aesar, 31.3\% Ru) at $298 \mathrm{~K}$ for $3 \mathrm{~h}$. The $\mathrm{Ru}$ concentrations in the impregnating solution were varied to change the $\mathrm{Ru}$ content. Impregnated samples were treated in ambient air at $398 \mathrm{~K}$ overnight and then at $673 \mathrm{~K}$ for $6 \mathrm{~h} . \mathrm{ZrO}_{2}$ was prepared by hydrolysis of aqueous $\mathrm{ZrOCl}_{2} \cdot 8 \mathrm{H}_{2} \mathrm{O}$ (Beijing Chemicals, Beijing, China) with excess $\mathrm{NH}_{3} \cdot \mathrm{H}_{2} \mathrm{O}(14 \mathrm{~N}$, Beijing Chemicals), followed by washing of the precipitates with deionized water until $\mathrm{Cl}^{-}$was no longer detected in the filtrate. These precipitates were dried at $393 \mathrm{~K}$ overnight and then treated at $673 \mathrm{~K}$ in ambient air for $6 \mathrm{~h}$.

BET surface areas were measured by $\mathrm{N}_{2}$ physisorption at its normal boiling point (at $101 \mathrm{kPa}$ ) using an ASAP 2010 analyzer (Micromeritics) after samples were treated at $393 \mathrm{~K}$ for $4 \mathrm{~h}$ in dynamic vacuum $(<2.66 \mathrm{~Pa})$.

XRD patterns were obtained in the $2 \theta$ range of $10-80^{\circ}$ on a Rigaku D/MAX-2000 diffractometer using $\mathrm{Cu} \mathrm{K} \alpha$ radiation $(\lambda=1.5406 \AA)$ operated at $30 \mathrm{kV}$ and $100 \mathrm{~mA}$. The average particle sizes $(D)$ were estimated by the Scherrer equation, ${ }^{18} D$ $=0.90 \lambda / \beta \cos \theta$, where $\theta$ is the diffraction angle and $\beta$ is the full width at half-maximum (fwhm).

XPS spectra were measured using an Axis Ultra spectrometer (Kratos, Manchester, U.K.) and monochromatic Al K $\alpha$ (1486.71 $\mathrm{eV})$ radiation at a source power of $225 \mathrm{~W}(15 \mathrm{~mA}, 15 \mathrm{kV})$. The binding energies were referred to a C1s peak at $284.8 \mathrm{eV}$ for adventitious carbon. Surface compositions were calculated from peak intensities using the sensitivity factors provided by the spectrometer.

Raman spectra were measured at ambient temperature using a Renishaw 1000 spectrometer equipped with a $\mathrm{He}-\mathrm{Ne}$ laser at a wavelength of $632.8 \mathrm{~nm}$ (model 127-25RP) and a CCD camera. The resolution was $2 \mathrm{~cm}^{-1}$, and the laser power was set to $1.2 \mathrm{~mW}$. Raman shifts for all of the samples were measured in the range of $100-1500 \mathrm{~cm}^{-1}$ in ambient air.

Methanol Oxidation Rates and Selectivities. Methanol oxidation rate and selectivity data were measured in a packedbed quartz microreactor ( $6 \mathrm{~mm}$ i.d.) using catalyst powders (80100 mesh, $0.2 \mathrm{~g})$, which were diluted with quartz ( $2 \mathrm{~g})$ to prevent temperature gradients and hot spots, and treated in $10 \%$ $\mathrm{O}_{2} / \mathrm{N}_{2}$ (Beijing Huayuan, 99.999\%) flow $\left(30 \mathrm{~cm}^{3} \mathrm{~min}^{-1}\right)$ at 673 $\mathrm{K}$ for $1 \mathrm{~h}$ before catalytic measurements. Reactants consisted of $3.5 \mathrm{kPa}$ of $\mathrm{CH}_{3} \mathrm{OH}$ (Beijing Chemicals, $99.99 \%$ ) and $10 \mathrm{kPa}$ of $\mathrm{O}_{2}$ (Beijing Huayuan, 99.999\%) with $86.5 \mathrm{kPa}$ of balance $\mathrm{N}_{2}$ (Beijing Huayuan, 99.999\%). All transfer lines between the reactor and gas chromatograph were kept above $393 \mathrm{~K}$ to avoid condensation of the products. Reactants and products were analyzed by on-line gas chromatography (Shimadzu 2010 GC) using two packed columns (Carbosieve $\mathrm{B}, \mathrm{O}_{2}, \mathrm{~N}_{2}$, and $\mathrm{CO}$; Porapak N, other components) connected to thermal conductivity detectors (TCD). Steady-state kinetic data were collected after $2 \mathrm{~h}$ on-stream. Selectivities are reported on a carbon basis and rates as molar $\mathrm{CH}_{3} \mathrm{OH}$ conversion rates per mole of Ru per hour. Blank experiments were conducted using empty reactors, quartz powders, and pure $\mathrm{ZrO}_{2}$ support without detectable $\mathrm{CH}_{3} \mathrm{OH}$ conversions at all conditions in this study.

Dynamics of Reduction of Dispersed $\mathrm{RuO}_{x}$ Domains in $\mathbf{H}_{2} \cdot \mathrm{H}_{2}$ temperature-programmed reduction (TPR) data were measured using a flow unit (TP5000, Tianjin Xianquan). Samples were placed within a quartz cell, and the temperature was increased linearly from 293 to $773 \mathrm{~K}$ at $10 \mathrm{~K} \mathrm{~min}^{-1}$ in flowing $5 \% \mathrm{H}_{2} / \mathrm{N}_{2}\left(50 \mathrm{~cm}^{3} \mathrm{~min}^{-1}\right.$; Beijing Huayuan, certified
TABLE 1: BET Surface Areas, Nominal Ru Suface Densities, Average $\mathrm{ZrO}_{2}$ Crystallite Sizes, and XPS Ru3d $5 / 2$ Binding Energies for $\mathrm{ZrO}_{2}$-Supported $\mathrm{RuO}_{x}$ Catalysts

\begin{tabular}{ccccccc}
\hline & $\begin{array}{c}\text { surface } \\
\text { Ru loading } \\
(\text { wt } \%)\end{array}$ & $\begin{array}{c}\text { Ru surface } \\
\text { area } \\
\left(\mathrm{m}^{2} / \mathrm{g}\right)\end{array}$ & $\begin{array}{c}\text { density } \\
\left(\mathrm{Ru} / \mathrm{nm}^{2}\right)\end{array}$ & \begin{tabular}{c} 
binding energy $(\mathrm{eV})$ \\
\cline { 5 - 6 } size $^{a}(\mathrm{~nm})$
\end{tabular} & species I & species II \\
\hline 0 & 116.0 & 0 & 7.9 & & \\
0.4 & 121.0 & 0.2 & 7.2 & 282.7 & \\
0.9 & 121.4 & 0.4 & 6.8 & 282.7 & 280.9 \\
1.9 & 120.2 & 0.9 & 7.1 & 282.7 & 280.8 \\
3.5 & 109.3 & 1.9 & 6.8 & 282.8 & 280.9 \\
5.5 & 105.3 & 3.1 & 6.8 & 282.8 & 280.9 \\
6.7 & 106.6 & 3.8 & 7.3 & 282.7 & 281.0
\end{tabular}

${ }^{a}$ Calculated from X-ray diffraction patterns for these samples by the Sherrer equation.

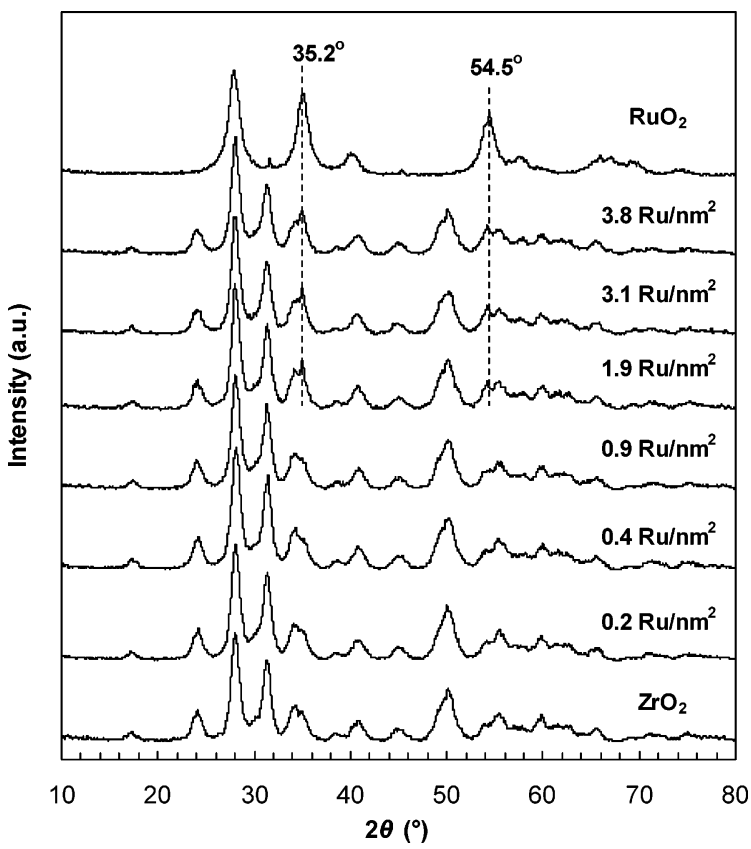

Figure 1. X-ray diffraction patterns for $\mathrm{ZrO}_{2}$-supported $\mathrm{RuO}_{x}$ catalysts with $\mathrm{Ru}$ surface densities of $0.2-3.8 \mathrm{Ru} / \mathrm{nm}^{2}$ and for pure $\mathrm{ZrO}_{2}$ and $\mathrm{RuO}_{2}$.

mixture). The amount of sample was varied so as to keep similar amounts of $\mathrm{Ru}$ (ca. $4 \mathrm{mg}$ ) within the cell for samples with various $\mathrm{Ru}$ contents. The $\mathrm{H}_{2}$ concentration in the effluent was measured by on-line mass spectrometry (Hiden HPR 20). The spectrometer response was calibrated by reducing $\mathrm{CuO}$ powders (Beijing Chemicals, $>99.0 \%)$ in $\mathrm{H}_{2}\left(5 \% \mathrm{H}_{2} / \mathrm{N}_{2}\right)$.

\section{Results and Discussion}

Catalyst Characterization. BET surface areas and nominal $\mathrm{RuO}_{x}$ surface densities are reported in Table 1 for all $\mathrm{RuO}_{x} /$ $\mathrm{ZrO}_{2}$ samples. The nominal $\mathrm{RuO}_{x}$ surface densities $\left(\mathrm{Ru} / \mathrm{nm}^{2}\right)$ were estimated from the Ru content and BET surface area. The surface areas, specifically for the samples with $\mathrm{Ru}$ surface density above $1.9 \mathrm{Ru} / \mathrm{nm}^{2}$, decreased slightly with increasing $\mathrm{Ru}$ content and surface density, as a result of the deposition of dispersed $\mathrm{RuO}_{x}$ on top of $\mathrm{ZrO}_{2}$ surfaces.

Figure 1 shows diffraction patterns for $\mathrm{RuO}_{x} / \mathrm{ZrO}_{2}, \mathrm{ZrO}_{2}$, and $\mathrm{RuO}_{2}$ [from decomposition of $\mathrm{Ru}(\mathrm{NO})\left(\mathrm{NO}_{3}\right)_{3}$ at $673 \mathrm{~K}$ ]. $\mathrm{ZrO}_{2}$ showed only monoclinic structures without detectable tetragonal phase $\left(2 \theta=30.2^{\circ}\right) .{ }^{19}$ Pure $\mathrm{RuO}_{2}$ gave intense lines at $2 \theta=$ $28.1^{\circ}, 35.2^{\circ}, 40.5^{\circ}$, and $54.5^{\circ}$; the lines at $35.2^{\circ}$ and $54.5^{\circ}$ do not overlap those for monoclinic $\mathrm{ZrO}_{2}$ and can be used to detect crystalline $\mathrm{RuO}_{2} \cdot \mathrm{RuO}_{x} / \mathrm{ZrO}_{2}$ samples with low $\mathrm{RuO}_{x}$ 


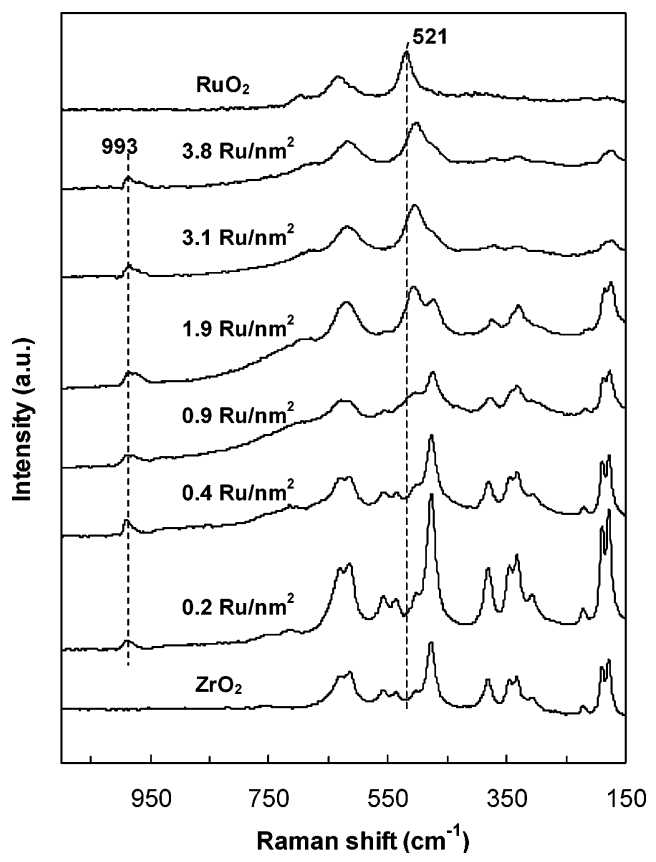

Figure 2. Raman spectra for $\mathrm{ZrO}_{2}$-supported $\mathrm{RuO}_{x}$ catalysts with $\mathrm{Ru}$ surface densities of $0.2-3.8 \mathrm{Ru} / \mathrm{nm}^{2}$ and for pure $\mathrm{ZrO}_{2}$ and $\mathrm{RuO}_{2}$.

concentrations $\left(<1.9 \mathrm{Ru} / \mathrm{nm}^{2}\right)$ showed only monoclinic $\mathrm{ZrO}_{2}$ and no crystalline $\mathrm{RuO}_{x}$, suggesting that $\mathrm{RuO}_{x}$ species were well dispersed on $\mathrm{ZrO}_{2} . \mathrm{RuO}_{2}$ diffraction lines appeared at $1.9 \mathrm{Ru} /$ $\mathrm{nm}^{2}$ and became more intense as $\mathrm{RuO}_{2}$ crystallites formed with increasing $\mathrm{Ru}$ surface density. The line breadth for the diffraction line at $2 \theta=28.1^{\circ}$ was used to estimate $\mathrm{ZrO}_{2}$ crystallite sizes, which ranged from 6.8 to $7.9 \mathrm{~nm}$ (Table 1), irrespective of $\mathrm{RuO}_{x}$ surface density.

Raman spectra (Figure 2) confirmed that only monoclinic $\mathrm{ZrO}_{2}$ was present in the $\mathrm{ZrO}_{2}$ support. Crystalline $\mathrm{RuO}_{2}$ showed three Raman bands at 521, 640, and $704 \mathrm{~cm}^{-1}$, corresponding to $\mathrm{E}_{\mathrm{g}}, \mathrm{A}_{1 \mathrm{~g}}$, and $\mathrm{B}_{2 \mathrm{~g}}$ modes; ${ }^{20}$ the band at $521 \mathrm{~cm}^{-1}$ does not overlap with the $\mathrm{ZrO}_{2}$ bands, and it can be used to detect crystalline $\mathrm{RuO}_{2}$ in $\mathrm{RuO}_{x} / \mathrm{ZrO}_{2}$. It was not detected for $\mathrm{Ru}$ surface densities of 0.2 and $0.4 \mathrm{Ru} / \mathrm{nm}^{2}$, but emerged as a weak shoulder at $0.9 \mathrm{Ru} / \mathrm{nm}^{2}$ and became stronger above $1.9 \mathrm{Ru} / \mathrm{nm}^{2}$, suggesting that crystalline $\mathrm{RuO}_{2}$ forms at surface densities $>0.9$ $\mathrm{Ru} / \mathrm{nm}^{2}$. The observed red shift of this band relative to bulk crystalline $\mathrm{RuO}_{2}$ appears to reflect the small size of supported $\mathrm{RuO}_{2}$ crystallites. ${ }^{20} \mathrm{~A}$ band was observed at $\sim 993 \mathrm{~cm}^{-1}$ in all $\mathrm{RuO}_{x} / \mathrm{ZrO}_{2}$ samples. Taken together with the XPS spectra and stoichiometric $\mathrm{H}_{2}$ reduction data, this new band can be tentatively assigned to terminal $\mathrm{Ru}=\mathrm{O}$ stretching vibrations for $\mathrm{RuO}_{4}{ }^{2-}$ species $\left(\mathrm{Ru}^{6+}\right)$ probably present in $\mathrm{Zr}\left(\mathrm{RuO}_{4}\right)_{2}$ structures formed via reactions of $\mathrm{ZrO}_{2}$ with $\mathrm{RuO}_{x}$ during treatment in air at $673 \mathrm{~K}$.

The presence of $\mathrm{RuO}_{2}$ and $\mathrm{RuO}_{4}{ }^{2-}$ species in $\mathrm{RuO}_{x} / \mathrm{ZrO}_{2}$ was confirmed by XPS. At low Ru surface densities (e.g., $0.2 \mathrm{Ru} /$ $\mathrm{nm}^{2}$ ), only a Ru3d $\mathrm{d}_{5 / 2}$ signal with a binding energy of $282.7 \mathrm{eV}$ corresponding to $\mathrm{Ru}^{6+21}$ was observed (Table 1 ). The structure of the $\mathrm{Ru}^{6+}$ species remains unclear, but it is unlikely to be $\mathrm{RuO}_{3}$ because of its thermodynamic instability and high volatility. This supports the presence of only $\mathrm{RuO}_{4}^{2-}$ species in this sample. As Ru surface density increased to $0.4 \mathrm{Ru} / \mathrm{nm}^{2}$, $\mathrm{RuO}_{2}$ structures formed, as shown by a feature with a $\mathrm{Ru} 3 \mathrm{~d}_{5 / 2}$ binding energy of $281.0 \mathrm{eV} .{ }^{21}$ The surface $\mathrm{Ru}^{6+} /\left(\mathrm{Ru}^{6+}+\mathrm{Ru}^{4+}\right)$ atomic ratio was estimated to be 0.90 for this sample; this value decreased monotonically to 0.39 as the surface density increased to $3.8 \mathrm{Ru} / \mathrm{nm}^{2}$ (Figure 3). Thus, the fraction of the $\mathrm{Ru}$ present

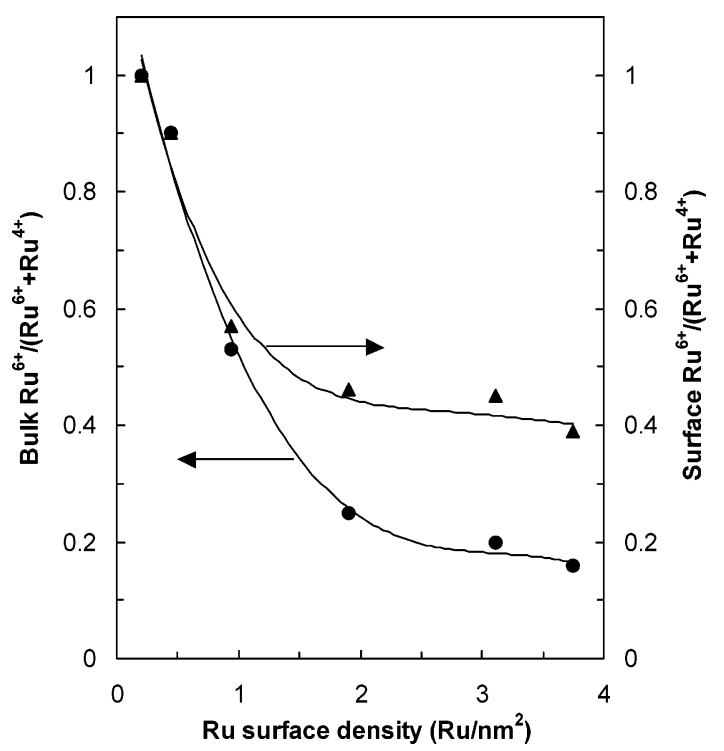

Figure 3. Surface (measured by XPS) and bulk (measured by $\mathrm{H}_{2}$ TPR) $\mathrm{RuO}_{x}$ fractions for $\mathrm{ZrO}_{2}$-supported $\mathrm{RuO}_{x}$ catalysts.

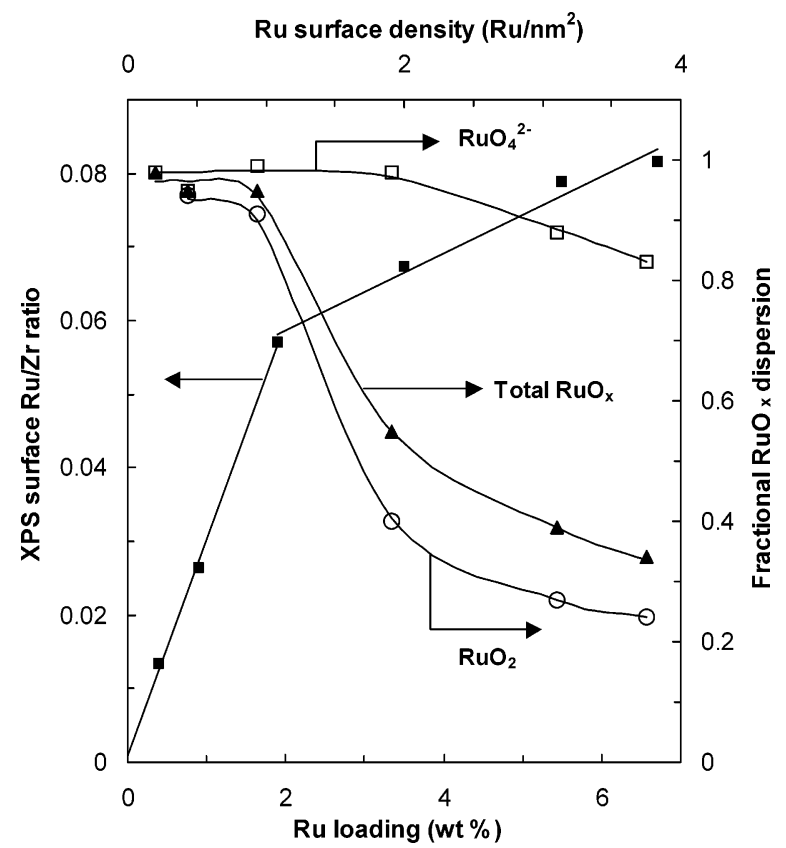

Figure 4. Surface Ru/Zr ratios (measured by XPS) and fractional dispersions of total $\mathrm{RuO}_{x}$ species and of respective $\mathrm{RuO}_{4}{ }^{2-}$ and $\mathrm{RuO}_{2}$ species (estimated by surface $\mathrm{Ru} / \mathrm{Zr}$ ratios from XPS) as a function of $\mathrm{Ru}$ content and surface density.

as $\mathrm{Ru}^{4+}$ increases with increasing $\mathrm{Ru}$ surface density at $\mathrm{ZrO}_{2}$ surfaces.

Figure 4 shows surface $\mathrm{Ru} / \mathrm{Zr}$ atomic ratios (including $\mathrm{Ru}^{4+}$ and $\mathrm{Ru}^{6+}$ ) for these samples as a function of Ru surface density. These $\mathrm{Ru} / \mathrm{Zr}$ ratios were initially proportional to the $\mathrm{Ru}$ surface density and then increased more slowly for surface densities above $1.9 \mathrm{Ru} / \mathrm{nm}^{2}$. The initial linear increase indicates that $\mathrm{RuO}_{x}$ species are highly dispersed on $\mathrm{ZrO}_{2}$ at surface densities below $1.9 \mathrm{Ru} / \mathrm{nm}^{2}$ and then aggregate to form $\mathrm{RuO}_{2}$ crystallites at higher surface coverages, as also observed by XRD and Raman. Such behavior is consistent with Stranski-Krastanov (SK) growth mechanisms, ${ }^{22}$ in which $\mathrm{RuO}_{4}{ }^{2-}$ and $\mathrm{RuO}_{2}$ are dispersed up to $0.9 \mathrm{Ru} / \mathrm{nm}^{2}$ and then three-dimensional clusters form. The "saturation" coverage at which crystallites form is much smaller than the theoretical monolayer coverage of $\sim 4-5 \mathrm{Ru} / \mathrm{nm}^{2}$ [for the $\mathrm{RuO}_{2}$ (110) plane]. ${ }^{10} \mathrm{RuO}_{x}$ dispersions were estimated from 


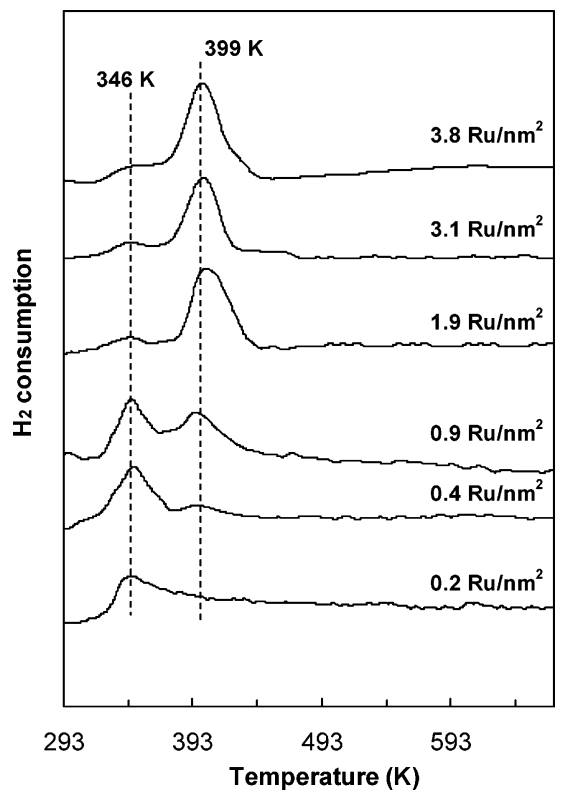

Figure 5. $\mathrm{H}_{2}$ temperature-programmed reduction profiles for $\mathrm{ZrO}_{2-}$ supported $\mathrm{RuO}_{x}$ catalysts with $\mathrm{Ru}$ surface densities of $0.2-3.8 \mathrm{Ru} /$ $\mathrm{nm}^{2}$ treated at $673 \mathrm{~K}$ in air.

surface $\mathrm{Ru} / \mathrm{Zr}$ ratios measured by XPS using a method previously reported. ${ }^{23,24}$ Figure 4 shows that fractional dispersions of toal $\mathrm{RuO}_{x}$ species were essentially constant at near unity (0.95-0.98) up to $0.9 \mathrm{Ru} / \mathrm{nm}^{2}$ and then decreased monotonically to a value of 0.34 as surface densities reached $3.8 \mathrm{Ru} / \mathrm{nm}^{2}$. This is consistent with the growth of $\mathrm{RuO}_{2}$ crystallites, as shown from the respective dispersions of the coexisting $\mathrm{RuO}_{4}{ }^{2-}$ and $\mathrm{RuO}_{2}$ species. $\mathrm{RuO}_{2}$ dispersions deceased sharply above $0.9 \mathrm{Ru} /$ $\mathrm{nm}^{2}$, but $\mathrm{RuO}_{4}{ }^{2-}$ species remained highly dispersed (0.85) even at $3.8 \mathrm{Ru} / \mathrm{nm}^{2}$, apparently because of their strong interactions with $\mathrm{ZrO}_{2}$ surfaces.

The bulk composition and oxidation state of $\mathrm{RuO}_{x}$ species in $\mathrm{RuO}_{x} / \mathrm{ZrO}_{2}$ were examined by temperature-programmed reduction (TPR) using $\mathrm{H}_{2}$ as the reductant. Only one reduction peak (at $\sim 346 \mathrm{~K}$ ) was present for the sample with $0.2 \mathrm{Ru} / \mathrm{nm}^{2}$ (Figure 5), and the reduction stoichiometry was $2.95 \mathrm{H}_{2} / \mathrm{Ru}$, similar to the value expected for stoichiometric reduction of $\mathrm{RuO}_{4}{ }^{2-}$ to $\mathrm{Ru}^{0}$ :

$$
\mathrm{Zr}\left(\mathrm{RuO}_{4}\right)_{2}+3 \mathrm{H}_{2} \rightarrow \mathrm{ZrO}_{2}+\mathrm{Ru}+3 \mathrm{H}_{2} \mathrm{O}
$$

Another reduction peak appeared at a surface density of 0.4 $\mathrm{Ru} / \mathrm{nm}^{2}$ as a shoulder (at $\sim 400 \mathrm{~K}$ ). Its reduction stoichiometry is consistent with the reduction of $\mathrm{RuO}_{2}$ to Ru metal. This $\mathrm{RuO}_{2}$ reduction feature became more intense relative to the $\mathrm{RuO}_{4}{ }^{2-}$ reduction peak with increasing Ru surface density (Figure 5). This can also be seen clearly from the bulk $\mathrm{Ru}^{6+} /\left(\mathrm{Ru}^{6+}+\mathrm{Ru}^{4+}\right)$ atomic ratios presented in Figure 3, showing that $\mathrm{RuO}_{2}$ species become prevalent on $\mathrm{ZrO}_{2}$ as Ru surface density increases.

Taken together, these characterization results indicate that $\mathrm{RuO}_{x}$ species evolve from dispersed $\mathrm{RuO}_{4}{ }^{2-}$ species, probably in $\mathrm{Zr}\left(\mathrm{RuO}_{4}\right)_{2}$ structures, at Ru surface densities below $0.4 \mathrm{Ru} /$ $\mathrm{nm}^{2}$ to dispersed and three-dimensional $\mathrm{RuO}_{2}$ domains at $\mathrm{Ru}$ surface densities $>1.9 \mathrm{Ru} / \mathrm{nm}^{2}$.

Methanol Oxidation Rates and Selectivities on $\mathrm{RuO}_{x} / \mathrm{ZrO}_{2}$ Catalysts. Figure 6 shows methanol oxidation rates (per Ru atom) and selectivities at $373 \mathrm{~K}$ as a function of Ru surface density on $\mathrm{RuO}_{x} / \mathrm{ZrO}_{2}$ catalysts. The rates and selectivities were compared at similar $\mathrm{CH}_{3} \mathrm{OH}$ conversions $(\sim 15 \%)$ because the extent of $\mathrm{CH}_{3} \mathrm{OH}$ conversion influences the relative contributions

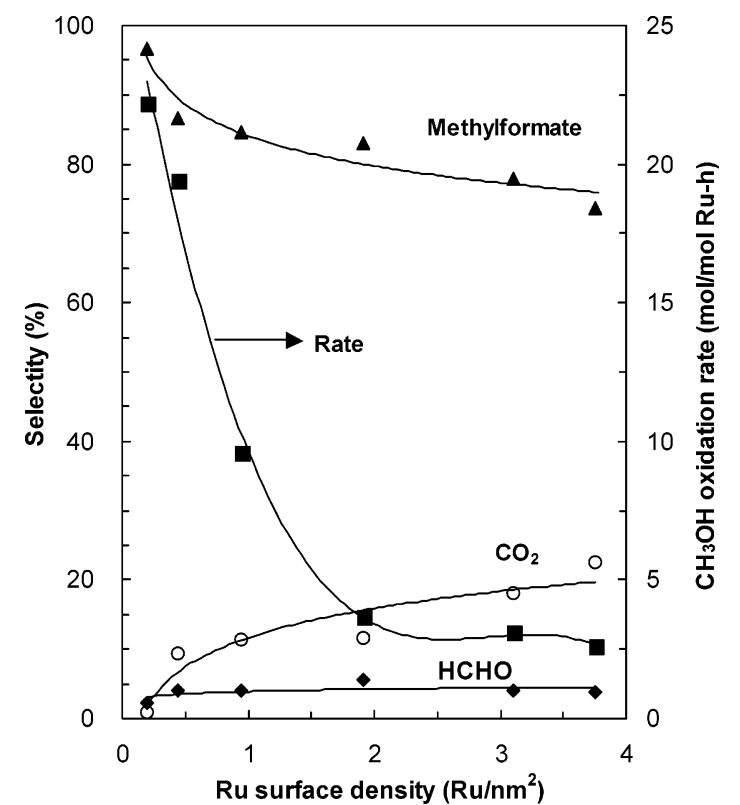

Figure 6. $\mathrm{CH}_{3} \mathrm{OH}$ oxidation rates normalized per $\mathrm{Ru}$ atom and selectivities as a function of $\mathrm{Ru}$ surface density at $373 \mathrm{~K}$ on $\mathrm{RuO}_{x} /$ $\mathrm{ZrO}_{2}$ catalysts at conversions of $\sim 15 \%\left(0.2-3.8 \mathrm{Ru} / \mathrm{nm}^{2}, 3.5 \mathrm{kPa}\right.$ of $\mathrm{CH}_{3} \mathrm{OH}, 10 \mathrm{kPa}$ of $\mathrm{O}_{2}$, balance $\mathrm{N}_{2}$ ).

of primary and secondary reactions. ${ }^{10}$ The rates and selectivities remained essentially unchanged with time (for $48 \mathrm{~h}$ ) on all samples. $\mathrm{CH}_{3} \mathrm{OH}$ oxidation rates (per $\mathrm{Ru}$ atom) decreased sharply as Ru surface density increased from 0.2 to $1.9 \mathrm{Ru} /$ $\mathrm{nm}^{2}$ and then more gradually at higher $\mathrm{Ru}$ surface densities. MF selectivities decreased monotonically from 96.6 to $72.6 \%$ with increasing $\mathrm{Ru}$ surface density (from 0.2 to $3.8 \mathrm{Ru} / \mathrm{nm}^{2}$ ) while $\mathrm{CO}_{2}$ selectivities concurrently increased (from 0.8 to 23.6\%). HCHO selectivities were low, which initially increased slightly with increasing Ru surface density, and then reached a constant value of $4.1 \%$ above $0.4 \mathrm{Ru} / \mathrm{nm}^{2}$ (Figure 6). By referring to the structural evolution of the $\mathrm{RuO}_{x}$ domains with the Ru surface density and dispersion, these results indicate that the dispersed $\mathrm{RuO}_{4}{ }^{2-}$ species seem to be more selective for the MF synthesis relative to the $\mathrm{RuO}_{2}$ species. The higher MF selectivities on samples with low Ru surface density may also be due to their higher exposed $\mathrm{ZrO}_{2}$ surface areas involved in the conversion of $\mathrm{HCHO}$ intermediates to $\mathrm{MF} .{ }^{10}$

At Ru surface densities below $1.9 \mathrm{Ru} / \mathrm{nm}^{2}$, especially for $0.2-$ $0.9 \mathrm{Ru} / \mathrm{nm}^{2}$, nearly all of the $\mathrm{Ru}$ atoms in $\mathrm{RuO}_{x}$ domains are accessible to reactants. For these samples, rates per Ru atom correspond to turnover rates and reflect the intrinsic reactivity of exposed $\mathrm{RuO}_{x}$ species. Therefore, the decrease in the rates in the $\mathrm{Ru}$ surface density range from 0.2 to $0.9 \mathrm{Ru} / \mathrm{nm}^{2}$ reflects a decrease in reactivity as a result of the structural change from $\mathrm{RuO}_{4}{ }^{2-}$ species to $\mathrm{RuO}_{2}$ species with lower reactivity. Above $1.9 \mathrm{Ru} / \mathrm{nm}^{2}$, dispersed and crystalline $\mathrm{RuO}_{2}$ domains became the prevalent structures. The observed decrease in methanol oxidation rates (per Ru atom) with increasing Ru surface density may reflect either the lower intrinsic reactivity of $\mathrm{RuO}_{2}$ domains relative to $\mathrm{RuO}_{4}{ }^{2-}$ or merely their lower dispersion. Turnover rates [i.e., rates normalized by exposed Ru atoms (including both $\mathrm{Ru}^{4+}$ and $\mathrm{Ru}^{6+}$ species) using Ru dispersion data in Figure 4] still decreased with increasing Ru surface densities (Figure 7), suggesting that the intrinsic reactivity for $\mathrm{RuO}_{4}{ }^{2-}$ is higher than that for $\mathrm{RuO}_{2}$ domains. In this case, $\mathrm{CH}_{3} \mathrm{OH}$ oxidation rates (per $\mathrm{Ru}$ atom) should increase in parallel with the $\mathrm{RuO}_{4}{ }^{2-}$ fractions in these samples, as indeed shown by the data in Figure 8. 


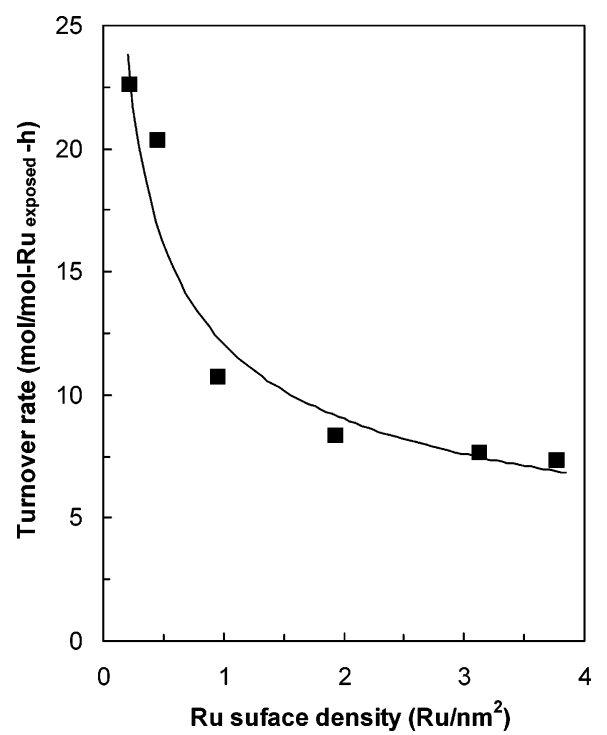

Figure 7. $\mathrm{CH}_{3} \mathrm{OH}$ oxidation turnover rates (per exposed $\mathrm{Ru}$ atom) as a function of Ru surface density at $373 \mathrm{~K}$ on $\mathrm{RuO}_{x} / \mathrm{ZrO}_{2}$ catalysts at conversions of $\sim 15 \%\left(0.2-3.8 \mathrm{Ru} / \mathrm{nm}^{2}, 3.5 \mathrm{kPa}\right.$ of $\mathrm{CH}_{3} \mathrm{OH}, 10 \mathrm{kPa}$ of $\mathrm{O}_{2}$, balance $\mathrm{N}_{2}$ ).

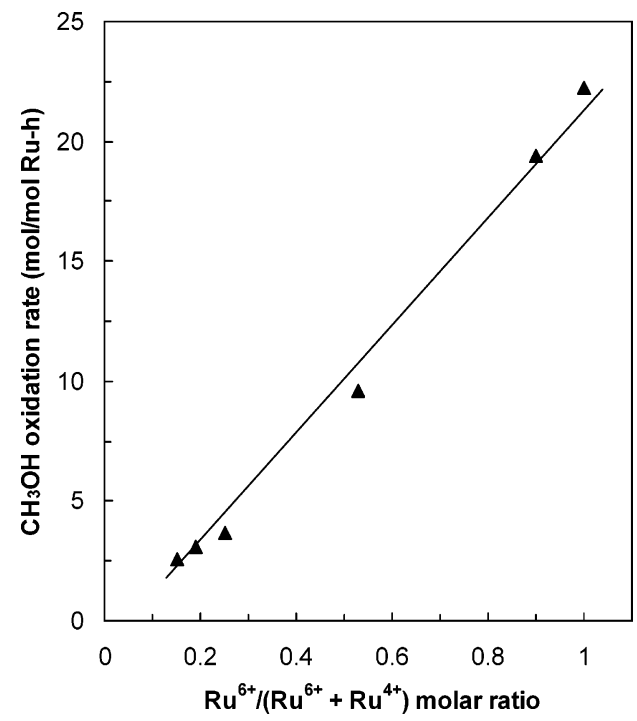

Figure 8. Dependence of $\mathrm{CH}_{3} \mathrm{OH}$ oxidation rates normalized per $\mathrm{Ru}$ atom at $373 \mathrm{~K}$ on the fractions of $\mathrm{RuO}_{4}{ }^{2-}$ species [represented as $\mathrm{Ru}^{6+} /$ $\left(\mathrm{Ru}^{6+}+\mathrm{Ru}^{4+}\right)$ molar ratios] for $\mathrm{RuO}_{x} / \mathrm{ZrO}_{2}$ catalysts $(0.2-3.8 \mathrm{Ru} /$ $\mathrm{nm}^{2}, 3.5 \mathrm{kPa}$ of $\mathrm{CH}_{3} \mathrm{OH}, 10 \mathrm{kPa}$ of $\mathrm{O}_{2}$, balance $\mathrm{N}_{2}, \sim 15 \% \mathrm{CH}_{3} \mathrm{OH}$ conversions).

The higher intrinsic reactivity of $\mathrm{RuO}_{4}{ }^{2-}$ relative to $\mathrm{RuO}_{2}$ is consistent with its more reducible nature. The peak temperature for $\mathrm{RuO}_{4}{ }^{2-}$ reduction was about $50 \mathrm{~K}$ below that for $\mathrm{RuO}_{2}$ reduction (Figure 5). The more reducible nature of $\mathrm{RuO}_{4}{ }^{2-}$ appears to reflect its higher $\mathrm{Ru}$ oxidation state and the atomic connectivity between $\mathrm{Ru}^{6+}$ and the less electronegative nature of $\mathrm{Zr}^{4+}$ cations in $\mathrm{Zr}\left(\mathrm{RuO}_{4}\right)_{2}$ relative to $\mathrm{Ru}$ cations in oligomeric $\mathrm{RuO}_{x}$ structures, which may favor electron transfer and activation of $\mathrm{Ru}-\mathrm{O}$ bonds during reduction in $\mathrm{H}_{2}$ and $\mathrm{CH}_{3} \mathrm{OH}$ oxidation catalysis compared with $\mathrm{RuO}_{2}$ structures. Clearly, $\mathrm{Ru}^{6+}$ species are more reducible than $\mathrm{Ru}^{4+}$, but cannot be stabilized against autoreduction without the formation of mixed structures with $\mathrm{ZrO}_{2}$. A correlation between reducibility and methanol oxidation rates is consistent with a Mars-van Krevelen cycle. It has been previously demonstrated for $\mathrm{CH}_{3} \mathrm{OH}$ oxidation using kinetic and isotopic methods, which showed that $\mathrm{HCHO}$ and $\mathrm{MF}$ form on $\mathrm{RuO}_{x}$ domains via redox cycles

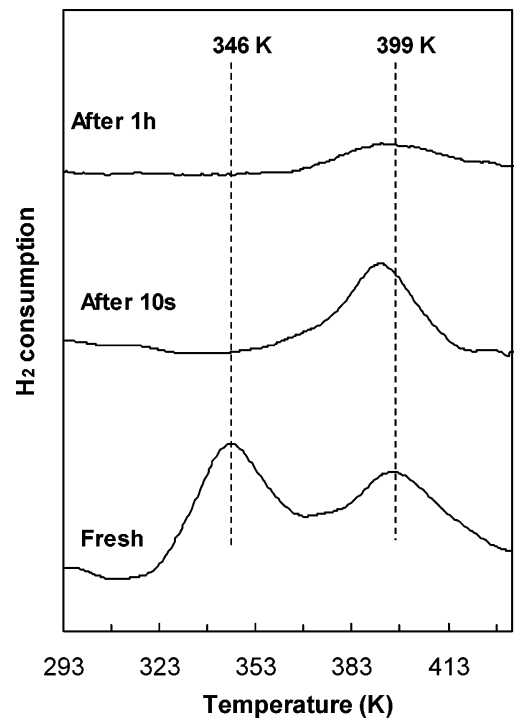

Figure 9. $\mathrm{H}_{2}$ temperature-programmed reduction profiles for $\mathrm{RuO}_{x}$ J $\mathrm{ZrO}_{2}$ catalyst with a Ru surface density of $0.9 \mathrm{Ru} / \mathrm{nm}^{2}$ before and after reactions with a $\mathrm{CH}_{3} \mathrm{OH} / \mathrm{N}_{2}\left(3.5 \mathrm{kPa}\right.$ of $\mathrm{CH}_{3} \mathrm{OH} / 96.5 \mathrm{kPa}$ of $\left.\mathrm{N}_{2}\right)$ stream for $10 \mathrm{~s}$ and $1 \mathrm{~h}$, respectively, at $373 \mathrm{~K}$ under anaerobic conditions.

involving lattice oxygen atoms and kinetically relevant $\mathrm{C}-\mathrm{H}$ bond activation steps. ${ }^{10}$ More facile reduction of the $\mathrm{RuO}_{x}$ domains leads to faster $\mathrm{CH}_{3} \mathrm{OH}$ oxidation turnovers, because transition states required for $\mathrm{C}-\mathrm{H}$ bond activation steps involve electron transfer and the local reduction of cationic centers in reducible metal oxides. Similar reactivity-reducibility correlations were observed for selective oxidation reactions of alcohols, ${ }^{10,23,24}$ dimethyl ether, ${ }^{15-17}$ and light alkanes ${ }^{25,26}$ on $\mathrm{MoO}_{x^{-}}$ and $\mathrm{VO}_{x}$-based materials, which also catalyze oxidation reactions via Mars-van Krevelen redox cycles.

The higher intrinsic reactivity of $\mathrm{RuO}_{4}{ }^{2-}$ structures was also evident from transient anaerobic $\mathrm{CH}_{3} \mathrm{OH}$ reactions on dispersed $\mathrm{RuO}_{4}{ }^{2-}$ and $\mathrm{RuO}_{2}$ structures that coexist in nearly equimolar amounts in the sample with $0.9 \mathrm{Ru} / \mathrm{nm}^{2}$. These transient experiments were conducted by controlled exposure of samples to $\mathrm{CH}_{3} \mathrm{OH}$ to attain a given extent of reduction via reactions between $\mathrm{RuO}_{x}$ domains and $\mathrm{CH}_{3} \mathrm{OH}$ under anaerobic conditions. Samples were then reduced in $\mathrm{H}_{2}$ by increasing the temperature from 298 to $673 \mathrm{~K}$ after removal of $\mathrm{CH}_{3} \mathrm{OH}$ from the bed with a pure $\mathrm{N}_{2}$ purge. Figure 9 shows that exposure to a $\mathrm{CH}_{3} \mathrm{OH} / \mathrm{N}_{2}$ (3.5 kPa of $\mathrm{CH}_{3} \mathrm{OH} / 96.5 \mathrm{kPa}$ of $\mathrm{N}_{2}$ ) stream for $10 \mathrm{~s}$ led to the complete disappearance of the lower temperature $\mathrm{RuO}_{4}{ }^{2-}$ reduction peak, present in the fresh sample, during subsequent reduction, whereas the peak corresponding to $\mathrm{RuO}_{2}$ reduction remained essentially unchanged. These data show that $\mathrm{RuO}_{4}{ }^{2-}$ species react with $\mathrm{CH}_{3} \mathrm{OH}$ preferentially over $\mathrm{RuO}_{2}$ species. After prolonged contact with the $\mathrm{CH}_{3} \mathrm{OH}$ stream, the $\mathrm{RuO}_{2}$ reduction peak also decreased in intensity (Figure 9), indicating that the $\mathrm{RuO}_{2}$ species can also participate in the $\mathrm{CH}_{3} \mathrm{OH}$ reactions, albeit with lower reactivity. Steady-state catalytic reactions of $\mathrm{CH}_{3} \mathrm{OH} / \mathrm{O}_{2}$ mixtures led to a $\mathrm{H}_{2}$ reduction profile (not shown in Figure 9) similar to that for the fresh sample, indicating that the reoxidation is fast and kinetically irrelevant during methanol oxidation catalysis and that $\mathrm{Ru}$ atoms exist predominately in their higher oxidation state during catalytic turnovers. This is consistent with the involvement of the redox cycles using lattice oxygen atoms in the $\mathrm{CH}_{3} \mathrm{OH}$ conversion to $\mathrm{MF}$ on $\mathrm{RuO}_{x}$ domains, as discussed above, and with the slow nature and kinetic relevance of the reduction part of the cyclethe activation of $\mathrm{C}-\mathrm{H}$ bonds in chemisorbed methoxide species. These observed effects of $\mathrm{RuO}_{x}$ structure on reducibility and 
catalytic properties may provide a fundamental basis for the design and synthesis of new catalysts for the $\mathrm{CH}_{3} \mathrm{OH}$ conversion to $\mathrm{MF}$ and other products and also for light alkane selective oxidations, for example, via the synthesis of more complete $\mathrm{Zr}$ $\left(\mathrm{RuO}_{4}\right)_{2}$ monolayers on $\mathrm{ZrO}_{2}$ or on other support structures with higher surface areas.

\section{Conclusions}

$\mathrm{ZrO}_{2}$-supported $\mathrm{RuO}_{x}$ domains catalyze the oxidation of methanol to methyl formate at low temperatures (e.g., $373 \mathrm{~K}$ ). $\mathrm{CH}_{3} \mathrm{OH}$ oxidation rates and selectivities strongly depend on $\mathrm{RuO}_{x}$ structure, which varied with $\mathrm{Ru}$ surface density $(0.2-3.8$ $\mathrm{Ru} / \mathrm{nm}^{2}$ ). $\mathrm{RuO}_{x}$ was preferentially dispersed as isolated $\mathrm{RuO}_{4}{ }^{2-}$ species below $0.4 \mathrm{Ru} / \mathrm{nm}^{2}$, probably as $\mathrm{Zr}\left(\mathrm{RuO}_{4}\right)_{2}$. At higher $\mathrm{Ru}$ surface densities, highly dispersed $\mathrm{RuO}_{2}$ domains formed, and then three-dimensional $\mathrm{RuO}_{2}$ clusters became prevalent above $1.9 \mathrm{Ru} / \mathrm{nm}^{2}$. Such structural evolution of $\mathrm{RuO}_{x}$ structures from $\mathrm{RuO}_{4}{ }^{2-}$ to $\mathrm{RuO}_{2}$ with increasing $\mathrm{Ru}$ surface density led to a linear decrease in methanol oxidation rates per $\mathrm{Ru}$ atom and per exposed $\mathrm{Ru}$ atom (turnover rates) as the $\mathrm{RuO}_{4}{ }^{2-}$ fraction decreased, indicating that $\mathrm{RuO}_{4}{ }^{2-}$ species are more reactive than $\mathrm{RuO}_{2}$ domains in the activation of $\mathrm{C}-\mathrm{H}$ bonds in methoxide intermediates, previously shown to control methanol oxidation rates on $\mathrm{RuO}_{x}$. These conclusions are consistent with transient anaerobic $\mathrm{CH}_{3} \mathrm{OH}$ reactions and $\mathrm{H}_{2}$ temperature-programmed reduction data, which show that $\mathrm{RuO}_{4}{ }^{2-}$ is more reducible than $\mathrm{RuO}_{2}$. The more reactive nature of $\mathrm{RuO}_{4}{ }^{2-}$ species and the higher exposed $\mathrm{ZrO}_{2}$ surface area on samples with low $\mathrm{Ru}$ surface density led to very high methyl formate selectivities ( $\sim 96 \%$ at $0.2 \mathrm{Ru} / \mathrm{nm}^{2}$ ). Taken together, these results show that $\mathrm{RuO}_{4}{ }^{2-}$ structures exhibit unprecedented reaction rates and selectivities for the synthesis of methyl formate from methanol$\mathrm{O}_{2}$ co-reactants.

Acknowledgment. This work was supported by the National Natural Science Foundation of China (Grants 20443010 and 20573004). This work was also supported in part by the Key Laboratory of Material-oriented Chemical Engineering of
Jiangsu Province and by the Program for New Century Excellent Talents in University (NECT-05-0010) and the Project Sponsored by the Scientific Research Foundation for the Returned Overseas Chinese Scholars, State Education Ministry.

\section{References and Notes}

(1) Tatibouet, J. M. Appl. Catal., A 1997, 148, 213.

(2) Lee, J. S.; Kim, J. C.; Kim, Y. G. Appl. Catal. 1990, 57, 1.

(3) Gerard, E.; Gotz, H.; Pellegrini, S.; Castanet, Y.; Mortreux, A. Appl. Catal., A 1998, 170, 297.

(4) Tronconi, E.; Elmi, A. S.; Ferlazzo, N.; Forzatti, P.; Busca, G.; Tittarelli, P. Ind. Eng. Chem. Res. 1987, 26, 1269.

(5) Ai, M. J. Catal. 1982, 77, 279.

(6) Valente, N. G.; Arrua, L. A.; Cadus, L. E. Appl. Catal., A 2001, 205, 201.

(7) Louis, C.; Tatibout, J. M.; Che, M. J. Catal. 1988, 109, 354.

(8) Busca, G. Catal. Today 1996, 27, 457.

(9) Liu, Y. C.; Griffin, G. L.; Chan, S. S.; Wachs, I. E. J. Catal. 1985, 94, 108

(10) Liu, H.; Iglesia, E. J. Phys. Chem. B 2005, 109, 2155.

(11) Iwasawa, Y. Acc. Chem. Res. 1997, 30, 103.

(12) Tada, M.; Iwasawa, Y. J. Mol. Catal. A: Chem. 2003, 204-205,

(13) Bell, A. T. Science 2003, 299, 1688 451

(14) Mestl, G.; Srinivasan, T. K. K. Catal. Rev.-Sci. Eng. 1998, 40,

(15) Liu, H.; Cheung, P.; Iglesia, E. J. Catal. 2003, 217, 222.

(16) Liu, H.; Cheung, P.; Iglesia, E. J. Phys. Chem. B 2003, 107, 4118.

(17) Liu, H.; Cheung, P.; Iglesia, E. Phys. Chem. Chem. Phys. 2003, 5, 3795 .

(18) Guinier, A. Theorie et Technique de la Radiocristallographie, 3rd ed.; Dunod: Paris, 1964; p 482.

(19) Xie, S.; Chen, K.; Bell, A. T.; Iglesia, E. J. Phys. Chem. B 2000, 104, 10059.

(20) Mar, S. Y.; Chen, C. S.; Huang, Y. S.; Tiong, K. K. Appl. Surf Sci. 1995, 90, 497.

(21) Chan, H. Y. H.; Takoudis, C. G.; Weavery, M. J. J. Catal. 1997 $172,336$.

(22) Shido, T.; Okita, G.; Asakura, K.; Iwasawa, Y. J. Phys. Chem. B 2000, 104, 12263

(23) Deo, G.; Wachs, I. E. J. Catal. 1994, 146, 323.

(24) Zhang, W.; Desikan, A.; Oyama, S. T. J. Phys. Chem. 1995, 99, 14468.

(25) Abello, M. C.; Gomez, M. F.; Cadus, L. E. Catal. Lett. 1998, 83, 185

(26) Chen, K.; Xie, S.; Bell, A. T.; Iglesia, E. J. Catal. 2001, 198, 